Planning at the national level in Europe in relation to major infrastructure

Tim Marshall

Department of Planning

Oxford Brookes University

Gipsy Lane

Oxford

OX3 0BP

UK

tmarshall@brookes.ac.uk

01865483931 


\title{
Planning at the national level in Europe in relation to major infrastructure
}

\begin{abstract}
This paper examines some recent cases of spatial planning at national level. Such planning may be comprehensive, in some rare cases, or sectoral and with a more fuzzy and complex character. The paper concentrates on how such planning at national level relates to the planning of major infrastructure in three European states. This reveals the wide range of approaches to such national level planning, with quite differing arrangements and recent trajectories. The political economic circumstances of recent decades are layered on top of more enduring constitutional and historicalgeographical characteristics, to frame the paths taken in each case. It is suggested that current arrangements are not likely to be up to the challenges now facing planning at this level. More careful academic focus on this level could help to suggest improved approaches.
\end{abstract}

\section{$\underline{\text { Introduction }}$}

Spatial planning is an activity which can in principle take place at any level or scale. Traditionally its fulcrum has been local or at the city level, but at different times and places, regional and national spatial planning has also had importance. Supranational spatial planning could also be an emergent phenomenon in an area like the European Union, where elements of sovereignty are pooled. The purpose of this paper is to examine the current circumstances of spatial planning at the national level in Europe. This is based on work in a research project focussed primarily on the planning of major infrastructure. It is not therefore intended to survey all types of spatial planning at the national level. However, major infrastructure forms a big component of the recently existing forms of such planning, and so a focus from this area highlights effectively, in the cases chosen, the most important aspects of recent national level spatial planning.

The contemporary forms of spatial planning at the national level are very different from those of the "last round" of spatial interventionism, which dated to a period 30 or 40 years ago when Keynesian state led programmes were the norm in western Europe. Then some countries had or were aspiring to strong national spatial strategies (Netherlands, Denmark, France, West Germany), as well as having strongly dirigiste approaches in the major infrastructure fields, where nearly all action was led by state owned corporations or boards. So elements of both comprehensive and sectoralised spatial planning were the norm, if in very varying forms. In the last decade, only one or two European countries retain national spatial strategies, with the Netherlands most prominent, alongside some newer cases likes the Baltic republics. Sectoral planning or strategising is also transformed, with very different amounts and characters being present across Europe. Overall far less strong state direction and control is the norm, given that, in several sectors, privatisation has reduced direct influence drastically. But this simple picture of a change of regimes is far from being the whole story, and it is this more complex picture that this article seeks to present, using cases from three western European states.

One reason for the interest in this phenomenon is that all states have aspirations to rise to new challenges in the main policy fields of infrastructure, including those of 
national competitiveness and responding to climate change. These are relevant in all policy fields, most obviously for energy and transport. Planning at the national level is one potential instrument to use to meet these challenges. But in the changed ideological landscape of the early twenty first century, what forms is this actually taking?

There has not been much study of this field in recent years. The core text is the collection of studies of planning at a national level edited by Alterman in 2001, examining 10 countries, including 7 in Europe. Since that time there has been very little writing about different experiences at this level, with more focus on the EU's territorial explorations level (Faludi and Waterhout 2002) and at times on subnational levels (Adams et al 2006). The absence of study may still reflect the continuing idea that the national state has been hollowed out. But there have been enough critiques of this idea, particularly by geographers (MacLeod 2001 was an early example, Goodwin et al 2005 on the "filling in" of the state), for this not to be taken as a hindrance to looking at what national governments really are doing. A more substantial block to effective study is perhaps the continuing difficulty of planners, and planning academics, in raising their eyes to big spatial questions, when more everyday local issues are so pressing.

The research is embedded within a larger project which has studied five EU states (France, Germany, the Netherlands, Spain and the UK)i. This includes separate treatment of UK-England and Scotland, therefore six cases. These were chosen to represent both different approaches to steering major infrastructure, including known differences in planning at national and regional levels, and some degree of commonality. All are within the EU and therefore have been affected by common pressures from EU policy making. Four of the six are large states, with only the Netherlands and Scotland, in different ways, being smaller and in some senses with less complex geographical and constitutional realities.

In this paper, the Netherlands is excluded from consideration, because of both its size, and the very different approach to national level planning. It is the only case with a continuing tradition of national spatial planning, which makes it a rather uncommon phenomenon in recent decades. Spain is also omitted. Its experience lies in some respects between that of France and Germany, with a semi-federal constitution and politics, and some central sectoral steering mechanisms reminiscent of French and German practice. This leaves three states, France, Germany and the UK, which are all quite large, but which differ on the three axes of analysis presented below (see Figure 1). These three states exhibit different approaches to managing the challenges of steering major infrastructure, but within the commonalities of EU governance and regulatory forces, and of containing dramatic internal diversity, geographically, constitutionally and politically. A major interest is to discover how, in the absence of formal national spatial planning (with the emerging exception of Scotland), steering in some form does nevertheless take place. What "soft" or "implicit" modes of planning or policy making are present in these cases? How do they relate to the contemporary capacities of states within their political economies? Can we recognise some common form of responses to the present challenges?

One question will remain at most in the wings - how far these countries may be delegating or allowing some role to the EU in this area. It is clear that a significant 
part of non-spatial policy making is occurring at EU level in recent years, whether in transport, energy, waste or water infrastructure fields, with the pressures for liberalisation and privatisation, alongside a certain environmental drive, being critical in all countries. But the direct steering of spatial dimensions remains smaller (I am thinking of areas like current territorial cohesion debates, TENS policy for transport and energy, in particular - for much more see Duhr et al 2010). I believe it is possible to analyse national level attempts in this area and abstract largely from EU policy. This is not to argue that these EU policy zones are unimportant. TENS transport and energy policy in particular are becoming more significant, and a further challenge is to analyse how these relate to the national planning efforts described here. But this would add a great deal to the area delimited for study here.

The same applies, if rather differently, to the fact that all planning and policy making is by necessity multi-level policy making. That is, if an element of infrastructure is to happen, whether point based (a port, airport, power station) or linear (roads, rail, transmission lines etc), the decision making on that element will occur at every level from at least the national to the local, with governmental and non governmental actors being variously involved at all these levels. The assumption here is that it is possible to focus on the national level component of this process, without thereby implying that the other components are not important. Just as the EU role is left aside, so those of the local and, largely, the regional are abstracted from. The aim is to highlight the nature of national level spatial planning, not to describe comprehensively all the elements which encompass the planning and implementation of major infrastructure.

The case studies were carried out in 2009 and 2010. Each contained extensive study of secondary literature, examination of policy documents within above all central government bodies, and interviews carried out during visits to central government ministries and other public agencies. In the most strongly federal or proto federal cases, Spain, Germany and the UK, some work was also carried out at the "regional" level (in Catalonia, Berlin-Brandenburg, and Scotland). However this was limited, with the aim of establishing the nature of activity at those levels, rather than conducting extensive research on particular infrastructure sectors. Full details of these studies are available on the project's webpages, which contain the working papers on which the following examination is based. These contain details of documents consulted, interviews carried out, and fuller arguing through of complex judgements.

The paper has three sections. The first presents the theoretical framing of the subsequent case studies. The second describes the situations in the case countries. This identifies distinctive and critical aspects rather than giving extensive accounts. The final parts bring this together in a discussion about the overall ways this area of public policy is playing out. This includes brief consideration of the degree to which we may we see the approaches adopted in national level planning meeting the current challenges in the major infrastructure fields.

\section{A framework for analysis of national level spatial planning}

There are naturally several different possible approaches to analysing spatial planning at the national level. One might draw on current planning theory to illuminate the kind of practices developed in each state. This is clearly the approach of several 
contemporary experts in studies of planning at local or regional level (examples could include Healey 2007, 2010, Albrechts and Mandelbaum 2005, Salet and Gualini 2007). This tended to see a certain revival of strategic planning in the 1990s and 2000s, and one might examine if this had transferred to higher planning scales. This could be useful in bringing out styles of planning, or perhaps common tendencies, which are seen to have flourished at subnational levels, and might be imagined to be present at national level too - perhaps drifts to new governance forms, to lighter approaches to steering, to networking types of planning, to mention the most obvious. However this approach is not the one adopted here. My judgement is that it gives less grip on change at the central state level than it does lower down, and that may be one reason why planning theorists have turned their attention rather little to the national level.

A second approach could be to try to draw on contemporary theorists of infrastructure and urbanism, who may be seen to have developed a "general theory" of how recent trends in the political economy of infrastructure industries have led to a fragmenting of public policy in this area, alongside a substantive fragmenting of networks themselves (Graham and Marvin 2001 and much subsequent literature, including Hodson and Marvin 2010 characterise this approach in the UK, whilst distinct schools exist in each European country, with French work - Dupuy 1991, Coutard 1999 being especially well known; Monstadt 2009 is one survey). In a way rather parallel to that of planning theory, this seems to me to give its best grip on local infrastructure systems - the continuous intersection with urbanism debates is not accidental. The city level, or at most wider city region, is the typical scale of focus.

Here a third approach is taken, linked more to wider political economic thinking, but without trying to extract a comprehensive theory from this. The approach taken to framing is eclectic, combining three elements, without trying to meld these together. Each must, it seems to me, be given its own autonomy and allowed to offer explanatory force. Whilst the aspiration to comprehensive theorising seems to me admirable, it is clear that this is tough and controversial. The lifetime wisdom of an expert like Wolfgang Streeck on his home territory of Germany (2009) shows how difficult such attempts to combine political, economic and sociological insights can be, and they require probably book length treatment.

The approach here seems necessary because this field amply surpasses the normal bounds of spatial planning. The challenges are societal, and very extensive in time and space. There are necessarily enormous tensions in the challenges currently perceived by governments and opinion formers in these states. A more processual approach typical of much planning theory, or one focussed primarily on infrastructure in itself, may not have the scope to include the explanatory elements needed. The approach here is framed around political economic, governmental and historical factors. All three dimensions are important.

The one most commonly analysed in academic fields, but not in "everyday planners talk", is that of political economy. There is a broad familiarity with the competing forms of explanation for more entrepreneurial or economic led planning forms in Europe in recent decades, with that promoted by Jessop and Brenner being perhaps that most drawn upon (Jessop 2002, Brenner 2004). Broadly, this argues that since the 1980s, west European countries moved out of the Keynesian state led era to a 
political approach called by Brenner the RCSR (Rescaled Competition State Regime). This is a high level theorisation, but was used by Brenner to characterise urban and regional policy change in the 1980s and 1990s. The debate continues, over a broad terrain, on how far explanation is helped or hindered by varying characterisation of "neoliberal" political economy (Brenner et al 2010, and forthcoming). A political economic approach with a similar sort of reach though different theoretical roots is that examining "varieties of capitalism" (Jackson and Deeg 2006, Schmidt 2002). This does at least allow some idea of national differences. Streeck (2009) argues for a much more comprehensive and substantive analysis of what has been common to capitalist countries over the last 30 years, based on a study of Germany. Here I simply stress the importance for comparative planning research, especially in this particular field, of drawing on these big political economic frames. To put it very baldly, all my case countries have, over the last 20 years, been swept along by the neoliberal flood tide, even though this has surged in nationally quite distinctive ways. Commonalities are as important as differences, especially given that all five states have been EU members for the main period studied, and therefore subject to those particular political economic regimes.

But such framing is not enough. Governmental and constitutional differences cannot be reduced to these political economic surges. German federalism, the continuing invention of Spanish multi-tensioned government, Gaullism and after, the gradual transforming of the UK - all of these are "partially autonomous" and need to sit also in the middle of an account of national level planning efforts. The work of political scientists like Lijphart (1999) helps to give a comparative frame for planning research, even though they are not so easy to apply, normally lying a decade or two behind current political drifts. Planning researchers have tried in the past to catch these differences with typologies, for example in those of Newman and Thornley (1996, 2005) identifying "planning families", drawn from different legal traditions largely, plus some idea of state form and governance differences. Some very broad classifications can be useful, for example the tendencies to consensualism or strong governmental alternation, and the tendencies to federalism or unitary government (the two lines of division used by Lijphart in his comparative work). But these only go so far, and it is often necessary to simply take the national specificities as one off cases, in all their distinctiveness. It is then essential to work out how this dimension intersects with the rather differently changing (generally faster moving) political economic dynamics. The interaction creates special possibilities and blockages.

But these two frames are also not enough. The third aspect to which attention is needed, is the historical geographies of countries, both in its hard material forms, and in its much more fuzzy imaginative force. On the one hand, this is a feature immediately raised in any comparative work - countries are larger or smaller, endowed with different water, energy, urban etc inheritances, more or less connected with other territories and remote bits of the world, and so on (cf Massey 2007). It is almost too obvious to be seen at times. But the imaginary side is much less obvious, and its excavation and any measure of its significance is much harder. The discussion in the cases remains limited here, given the risk of appearing insubstantial and hard to fix. It is though, I think, important especially at this national level of spatial policy steering or managing. What is in policy makers heads forms a policy baggage as they meet in the multiple governing spaces, giving shape to limits and openings. Do they have definite ideas of a country's geography, if so in what form? Nationalism, ideas 
of places in the wider world and within subnational territories, countries as economic machines - all this and much more comes into this dimension. Much is rather long lasting, even if sudden changes like the reunification of Germany or the new forming of the Spanish state in the post 1975 years, may give occasional speed ups - each was a political-constitutional event, as well as the forming of new geographies. It would be oversimplifying to say the three dimensions run from fast to slow change, but there is some truth in that. At any rate, there is a complex interaction, which case studies need to make visible and comprehensible. These spatial-historical combinings make planning effort at the national level quite a challenge to analysis, but also increase its fascination.

One reason why it is so important to make this third dimension conscious, is the clear turn in the last years to longer timescales in planning discussion. It is now not unusual to project changes several decades ahead, certainly in debate on energy and some other environmental issues. This means that the large material facts come into more focus, as does the wider spatial reach, encouraging much more analysis at large and even continental scales. The tension with the short term of much economic debate (emerging from the recession or financial crisis) is then extreme, and is hard for planners or politicians to manage. But the national level is largely the natural home for such debates to meet.

Clearly such a three way framing does not constitute any grand theorising. There is no doubt that there are some links between the movements in capitalism and the changes in government and governance in recent decades, as numerous theorists have tried to show, perhaps Jessop most impressively $(2002,2007)$. But unravelling the links is well beyond what is attempted here. Certainly for present purposes each dimension must be treated as largely autonomous.

It should be stressed that there is no simple embracing of a regime change model here, such as characterises the work of Brenner (2004), whereby we can say that all national level planning has taken a broadly common colour. Despite elements of commonality, such a model does not meet the evidence presented here, precisely because of the need to bring in with real force the other two framing elements.

\section{European case studies}

\section{France}

In all three case countries, talk of formal national planning would be out of place and time, except perhaps in the three smaller parts of the UK - in Scotland, Wales and Northern Ireland devolution of governing powers has encouraged since 2000 work on spatial strategies for these jurisdictions. This UK work can however be seen as more like that of German states or Spanish autonomous communities, though in some respects the UK cases have more autonomy, in some respects less.

France had a national planning system between the 1960s and 1980s, with a strong spatial component. The planning was primarily economic, led by the very strong levers possessed by the French state, which included at one time or another total ownership of all infrastructure industries, as well as control of large parts of the industrial economy, including cars, defence, elecronics, as well as many banks. The 
economic planning system decayed in the 1980s, and the last plan was abandoned in 1991, though the Commissariat du Plan was not abolished till 2005. The spatial component was formalised in 1963, with the formation of DATAR, a lean but at times powerful agency of around 200 staff (smaller than the Dutch National Physical Planning Agency at its height). This changed its name in 2006, to DIACT, but continues to have broadly the same sort of coordinating role, but with declining political clout since the 1980 s.

Characterising French national planning arrangements now is not easy. The view from French academics is that in reality, little is left of any force at this level. The twin drives since the 1980s of regionalisation and privatisation are seen as having hollowed out the capacity and political wish to do much at national level. There is no doubt that this is a large part of the story. In the 1970s the government machine, advised and prompted by DATAR, could steer economic and urban development to the balancing poles selected around France and within the Paris region, equipped across the sectoral board, with investments in transport, energy and so on. The attempt by the Jospin government of 1997 to 2002 to bring in a more planned approach, through the Schemas de Services Collectifs, was not successful, undermined by the more neoliberal approach of governments since then. The current system is a much more fought out multicentred one, whereby local, regional and private power centres negotiate with central government over the allocation of funds and other resources. This applies as much to some big transport infrastructure like high speed rail, as to more traditionally localised sectors. A high speed rail route, though relying on a national schema drawn up every few years, relies for its real implementation on labyrinthine deals between all levels of government, to try to get the money to persuade RFF (the track body) and SNCF (who run most long distance trains) to cooperate.

In many ways this picture of a much more complex and distributed decision making reality is correct. It does mean that the results are rather incremental. The fact that national schemas exist for roads, rail, energy transmission systems (gas, electricity), power stations, to a degree ports and airports, does not translate automatically to action. That comes through the interplay of the now established (though still evolving) political economic and governing regimes, formed since the 1980s. DIACT has limited powers to impose a spatial coordination on this, though it does lead on EU regional funds, as well as national-regional finance schemes, so some rough distributive logics can operate, within political imperatives. Territorial management was always a part of the overall national economic planning drive, and when that was largely wound up, it had not the autonomous power to continue in its old form.

However there are some respects in which this characterisation overplays the changes. Seen from my perspective, there remain certain structuring forces which do I think mean France has some elements of spatial steering for the country as a whole. Certainly the control over this is distributed, above all between public or semi public power centres, to some extent across to purely private powers. But that does not mean the sense of national direction is absent, simply that it is a shared endeavour. This is so in at least three ways. First there exist the national schemas I referred to above, for transport and energy sectors, backed by systems of financing and approval, much of which is still directly or indirectly in central ministries. Though regions are strong in certain areas, such as regional rail, they have not been able to become a 
powerful force in regional planning, with perhaps one or two exceptions of very active regions. So the overall transport and energy schemes or strategies retain their force, mapping out corridors or nodes within the geography, in a way that no lower body or private actor can do. This does not apply to waste matters, which are largely at very local level, and water is dealt with by the Agences de l'Eau, in six large river basin areas - but these do not fit the regions and so the ministry at the centre can still have some say here.

Furthermore, the ministry has produced an overall transport schema, for all modes and for maintenance as well as new investment. This Schema National des Infrastructures de Transport (SNIT) was published in draft in July 2010, much delayed. It is very controversial, not least as it provides for 900 kilometres of new motorways, alongside much larger rail investment, against a promise of no new motorway building. At any rate it will seek to continue the central role in this field. In the energy fields both gas and electricity industries are required by the EU to cooperate nationally to draw up transport/transmission plans. These will emerge in the next year or two. So this too will update planning systems maintained by the previously purely public energy companies. Power generation decisions are taken by EDF and the other energy companies, but in direct and tight collaboration with the top of the state.

Alongside this definitely spatially strategic work, there is a range of investment still undertaken by the state, which requires implicit or explicit geographical understandings. Vast public investments have gone into the two premier French ports, Le Havre and Marseille, and these will continue. Lesser investments go to the smaller ports, which are seen as more shared with the regions now. The same applies to the Paris airports and then the rest, even though this sector is more self financing, as elsewhere. In both sectors decentralisation of powers occurred in the mid 2000s, but this did not shift to a more market led system as in the UK. The central state still controls the top division of such investments, and increasingly the regions or big cities control the second division. The same applies in the continuing big investment in roads and rail. Though financing is often shared, it is central government who has the strongest handle on the overall limits and options in these networks.

Some of the sectoral schemes may have a cohering effect, given the importance of road and rail in structuring, combined with the airport and port implicit schemas. That is to say, as the debate on the TGV system has run on over the decades, this has served as a proxy or element of national spatial structuring, the balance of the nation's development and integration. In analogous ways, investment in ports and airports, and their land connections, may have the same effect. Road network decisions have a perhaps more incremental and often more localised nature, after the initial decisions of the 1950s/1960s. The overall forms of sectoral planning will be in the minds of territorially attuned ministers and especially civil servants.

The third way in which such continuing national understandings play out, is in the impetus given by half a century of state led strategising and the enduring idea of a whole nation which infuses French politics. There is it is true a sort of double headed character to the national imaginary, swaying back and forth around Paris first, and the decentralising forces of recent decades. But this double headedness is in a sense stabilised, so that all governments must accept it, and draw out the implications for national infrastructure networks and investment. This is partly path dependence, now 
a really powerful force, given the motorway and high speed rail systems built over 40 years, and the nuclear power plant economy, and gas and oil pipelines, from the same period. National spatial strategising naturally works largely within the tramlines laid out by this investment, with now no ideas of massive new schemes, or new cities, or new development poles.

This raises enormous dilemmas in current politics. The Sarkozy regime committed itself in 2007 to an ecological new direction, to emerge from a big national debate, the Grenelle. This set ambitious trajectories for many sectors, especially those most important for low carbon (transport, buildings). Much has been set in motion, including some green fiscal measures, and tweaking of big investment programmes, including continuing rail investment. But much has been very difficult, with the dropping of a carbon tax in 2010 being the latest casualty. The Grenelle was not explicitly spatial, but it had massive spatial implications. Whether deliberately or not, linking to DIACT was weak. The likely result will be a tendency to business as usual, that is no challenge at all to the spatial structure of the country formed since the 1960 s, around a high energy, high movement society. At any rate this is what the national imaginary overall expects to happen, divided though it may be between a view from Paris or from one of the big regional centres.

The substantive outcome is doubtless of a country making a systematic effort to decentre itself since the $1960 \mathrm{~s}$, with regional growth poles, though with this balanced by a continuing centralising policy which fits the airports and high speed rail systems as they have developed. Partly this is about the size of France, where there is more room for the play of centrifugal and centripetal forces than in the Netherlands or even England. It is also due to the historical form of the state, the Netherlands being to some degree polycentric, and France having the dominating position of Paris. Paris's domination has however never been so large as to trump automatically all alternative forces, as might happen in a smaller country. So to some degree the tension is built into the historical-geographical nature of things. This is given force by the democratic and pluralist form of French politics.

Overall a continuing tradition of national spatial thinking therefore exists, based on a mix of old, sectoral, and continuing work by DIACT, with the recent boost of Grenelle work. This continues to give a sort of mental scaffolding for an implicit habit of national strategising, in and outside government. That such a substantive spatial formula exists must be in part due to the national spatial imaginary, which may also be imagined as clustering round the two poles, more radial, and more matrix/ polycentric conceptions of French territory (and its insertion in wider Europe). There may be therefore be some sort of "match" between the substance of state policy and the imaginary, both in the same constant tension of the two poles, centralising and dispersing. This is therefore a less settled imaginary than in some more compact states (the Netherlands, Denmark), with less coherent and continuous debating, perhaps precisely because of the faultines such debate has to continually negotiate, giving less room for some sort of consensus grounds. However the rather strong commitment to a national future which lies at the core of the imaginary, powered by French nationalism, means that the risk of a breakdown in conversation is generally not too high. Up to the present, the ability to conjugate national, regional and local goals has permitted a roughly accepted double strategy, as described. 
I have tried to characterise the national approach in France as one with some continuing force, though it is certainly a lighter spatial steering system now, and one which is less transparent. This reflects the two big changes in the political economy and governing systems, which have reduced the force of the Jacobin state. I think that my third dimension supports this level of medium national cohering. France is by its basic and recent historical geography fixed to a certain spatial framing, which sets limits to the role of big territorial planning. French infrastructural development has been marked by high conflictivity over the last 20 years or more, and so the system has to work with the grain of these fights. The melding of national, regional and local governing structures helps this process, as does a certain shared idea of France.

I find this a fascinating spatial settlement, an evolved formula of a composite state finding ways to manage its spatial futures. As I have suggested, this is far from dealing with the big substantive dilemmas, but in process terms, it is a clear model of how a decentralised unitary state can manage in the current era.

\section{Germany}

As a formally federal country, with a history, in its western part, stretching back now 60 years, Germany has a clearer set of ground rules than other major states (UK, France or Spain). Reunification 20 years ago certainly administered a shock to these ground rules, but up to now, there has been little change to the established system. It is also a more unified country than Spain, in the sense of a common language and to a degree common culture. Cooperation is built into the system, and is expressed in the polycentric nature of the country, with no dominating capital as in France or Britain. It is also a country which is keen on planning, with a heavy respect for thinking forward and obeying legal agreements.

All these factors contribute to the picture of national planning arrangements. Firstly, they do exist, to a significantly greater extent than in the UK, France or Spain. Secondly though they are weak, only allowed by the constitution to go so far. Thirdly, they are, as in most countries, more sectoral than comprehensive, meaning that it is not easy to judge how far they are important or not, within this overall judgement of weakness. The overall complexity of German planning contributes to this difficulty in assessment.

Three elements make up the core of the arrangements as they have worked in recent years. Just one is a largely independent product of the federal government, the spatial planning report (Raumordnungsbericht, ROG), supposed to be produced every 4 or 5 years. This is written by the BBSR, the research body for the ministry which includes planning, as well as transport, building and urban policy (the BMVBS). The ROG is seen by some German planners as very important, bringing together a well researched evidence base for the whole of Germany, often with European comparisons. It therefore identifies the big trends across the whole countries, such as demographic and economic shifts, transport systems changes, ecological system changes. The work is respected, and so can be drawn on by the federal parliament and by other agencies. Judging its force is hard - it is hardly a best seller, with a low media profile, and there is little impression that the sectoral spending ministries take great notice of it. But it does set some of the terms of informed debate. Equivalent work exists from the relevant research bodies in France and the Netherlands, but that for 
Germany impresses most for its analytical base across many fields. This is supplemented by the existence of another all-Germany body, the Akademie fur Raumordnung und Landesforschung (ARL), outside government, but bringing together planning experts across Germany, and publishing a lot. The UK and Spain are notable for having no such properly researched government overview.

The second element of national planning effort is more shared with the 16 federal states, and reflect that the constitution does not give the federal government any direct role in planning, beyond setting framework legislation (or, after the 2006 federal reform, setting such planning norms as it considers appropriate - powers are now concurrent with the states). This framework legislation has been very important, but it is not spatialised. The main role is therefore cooperative, with the ministerial grouping of planning ministers being one important forum for discussion by the states, and the federal ministry. This body, the MKRO, meets regularly, and has committees looking at many detailed issues, serviced by the BBSR and with outside involvement. It keeps a wide range of issues under review. Given that the federal ministry is a full member (normally in such states conferences, the federal voice is only present as an observer), and that it provides the secretarial role, it can influence work programmes, and generally pushes for cooperative action. Such action has included since reunification two rounds of light steering of spatial affairs, in 1993-95 and in 2006 (for latter see MKRO 2006 and Aring and Sinz 2006). The first had a strong transport emphasis, especially knitting up the two Germanies, and the second was perhaps looser, but is considered by the ministry and BBSR to have set much of the agenda during the last five years. Each drew on the ROGs produced just beforehand.

These short documents are nothing at all like national spatial strategies. They are called "Leitbilder", something like conceptual guidelines. They encapsulate certain minimum shared values, about for example the importance of economic competitiveness, access to good living conditions and responding to environmental challenges. They do not seem to resonate much in sectoral planning, even in the same ministry, and no doubt play mainly to those within the planning community in the states. They seem to be a clear example of a very light touch spatial planning appropriate to a "very federal" federal state. In that sense, I suspect they are of real interest to other countries, showing how perhaps, with the ROG, and backed by a continuing tradition of ministerial conferences, collaborative thinking about futures can work. The essential elements are regular collaboration of central government and subcentral government, a secure independent research agency, and a commitment to spatial planning more widely.

The MKRO is important even in the absence of Leitbilder type documents, in that it continually pushes for collaborative elements in planning. These have been evident in a range of areas recently, including transport, energy and water, in infrastructure fields. This has intersected for example with transport work, and pushed forward governmental light style planning for ports and for airports (both sectors are the responsibility of the states, not the federal government). This planning has its limitations, not able to constrain actions of the states much. But the federal government seeks to weld all governmental levels together in these areas to maximise effects. This is easier for ports, where northern coast cooperation is already quite significant, than for airports, where the low cost carrier boom opened up niches for 
each region to aspire to international airports, much to the federal government's annoyance.

The third area of national planning effort is doubtless the most important. This is the process of transport infrastructure planning, carried out by the federal ministry as one of its core tasks. The headline product is the Bundesverkehrswegeplan (BVWP), produced about every 10 years, to cover all federal funded investment in roads, rail and waterways. This is very definitely a sectoral planning process, which uses cost benefit analysis approaches common to transport planning fields. But there is a spatial planning component. This was formally built into the making of the 2003 BVWP, and is likely to be a part of the next one, expected for 2015. How well this attempt to steer transport investment according to spatial planning criteria works is open to much argument. There are real doubts that the government can really take a strategic view of the whole system, given current constitutional arrangements, and the methodology of the BVWP. Here I only refer to it as an important potential element of national planning, which seeks to break down sectoral planning silos.

In other areas of infrastructure planning, such silos seem quite powerful, or at least there appears to be little read across at federal level. Powers in the areas of water, waste, energy and, as already said, ports and airports, are at state levels, so this may be unavoidable. As in Spain, the main hope that some sort of integrated planning is occurring must rest in the state planning processes. Where issues are more genuinely all-German, then the informal or formal collaborative arrangments must come into play in these sectors, to make sure that electricity lines make sense across the whole territory, or river basins are planned together. On the latter there is little to fear, as German river basin planning is well established, and has been further reinforced by the Water Framework Directive generation of plans produced by 2009. On power lines and gas pipes, the system largely relies on company planning logics, but this will be reinforced also by EU procedures now being worked on, requiring cross company collaboration to produce comprehensive forward plans for all Germany. At any rate the federal government has a strong central energy policy, which gives powerful indirect spatial messages to the states, on power generation (wind, nuclear etc). So in this sector a solid non-spatial framing does exist.

How does this raft of "light federal" planning roles fit the three dimensions analysed earlier? Most obviously, they are heavily determined by the governmental system, in all its complexity. But also the German transition to privatised and liberalised capitalism is quite visible, with the rise of powerful energy corporations having a much larger role in energy planning than in the past, and Deutsche Bahn, though still very dependent on federal funds, acting partly like a private actor in deciding which of the BVWP rail schemes to implement sooner, which later. But as in France (and the Netherlands and Spain), this is still moderated by considerable governmental leadership, leaving the collective German state (federal plus states) in quite a strong position across most infrastructure sectors. This is no doubt boosted in part by a shared national imaginary, though the power of the states means that this should not be overemphasised. This imaginary helped to carry out the massive infrastructural effort that has been the post 1990 investment in east Germany. That boosted the federal role for many years, including the elements I have described above. But that may be now tailing off, leaving a strong "states first" feeling amongst the richer states. Thus there are different historical movements overlying each other in this 
case, with that underlying being the overall (west) German governmental system, and the enduring sense of the country, mixing in the last 20 years with the challenge of reunification. Overlying this, and pushing in a sense in the other direction, is the force of privatised corporations in some sectors, and of market ideology more generally.

The net result is a weakening of national level planning efforts and impact, despite the reunification boost. Without the forces of neoliberalisation, one might have expected the last two decades to have been quite planning friendly. For the big challenges facing the country, a strong federal role might have been indicated - ecological challenges are not so easy to manage within each state, German geography (energy, water, travelling, airport locations) does not fit the borders of 16 states, the poverty of half the states might have called for a much bigger and more interventionist regional policy. All this was watered down by the call for less spending and less redistribution, and more power to the private sector.

Nevertheless, the German case remains extremely interesting, showing how national level planning can achieve something in not that auspicious circumstances, in a cold climate. It could have relevance in other countries, whether federal or not, as a pointer to collaborative and research based approaches.

\section{$U K$}

There are now four different planning systems in the UK (Haughton et al 2010). Here I concentrate on aspects of two, for Scotland and England, with most emphasis on the latter. It is well known that the UK is the most neoliberalised case in western Europe, with privatisation linked to liberalisation far advanced over the last 30 years. This has had peculiar effects on planning, and particularly on the national level planning arrangements. The governmental system is also a peculiar combination now, with major devolution of planning powers to Scotland, Wales and Northern Ireland for the last 10 years, alongside strong centralisation for England by the UK government. The position in Scotland is summarised briefly, before spending more time on the recent English changes.

Scottish planning was always slightly more spatially interventionist at national level than elsewhere, even before devolution in 1999. Since then two editions of a national spatial framework have been made, the second with statutory weight. In the midst of this second framework was a list of 14 key infrastructure projects, whose inclusion within the framework gave them in principle approval, subject to normal local inquiry and related procedures. Infrastructure issues were at the core of both frameworks, a sign perhaps of the infrastructuralism seen to afflict all contemporary states, but especially small states trying to both boost themselves in international competition and confirm democratic popularity. The framework is less definitive on other locational issues, tending to leave this to city region or local plans. The new system reflects the wish of a new polity to make its mark on its new territory, though given the shortage of funds and dependence on private companies (both reflections of the political economic era), this is not easily done, in moving from planning to implementation. The Scottish system therefore is born of both new governmental arrangements, and political economic realities. The decision to include the big infrastructure projects in a national strategy is an unusual one, somewhat reminiscent 
of the Dutch National Spatial Strategy, but even more definite than that. It contrasts strongly with the English new system, which was invented only shortly afterwards.

English town planning policy since 1988 has taken the form of national planning guidance for the making of local plans and development decisions, plus some regional guidance (to be abolished, at the time of writing). No spatial planning at national level has existed in England, and sectoral planning has been patchy, largely resisted in all sectors except that of roads and airports. This reflects the dominance of market ideology since the 1980s. The infrastructure regimes brought in at privatisations between 1979 and 1997 included quite strong regulatory regimes, but these were often non spatial. In some cases this was a difficult line to hold, as in water, split between an economic and an environmental regulator, and airports, which had a strong steering mechanism over each major airport. Rail was also implicitly spatial, given the challenge of regulating a monopoly. Roads were rarely privatised, so control and planning remained within government. The result was a complex mix of non integrated state-market mixtures. Some argued that this disguised a pro southern England geographical prioritising (Massey et al 2003), but this, which doubtless has existed, emerged from the political and economic aims of governments, more than any direct policy making. By the early 2000 s the call for a spatial strategy for England was commonly being made, to coordinate government action across all sectors more effectively. Up to the present this call has been resisted, largely it seems on grounds of neoliberal ideology - "the market" should determine the location of investment decisions, subject to overall regulatory regimes and local planning approvals.

At the time of writing no English spatial strategy exists, but the arrangements for national planning efforts have undergone significant changes over the last 3 or 4 years. The main national level innovation has been the system set up by the 2008 Planning Act, to make National Planning Statements (NPSs) for infrastructure sectors, as the basis for faster decision making by an independent body, the Infrastructure Planning Commission (IPC). The IPC is to be abolished by 2012, but its role will be essentially kept, with the aim of retaining the fast decision process. The government formed in May 2010 is retaining the core of the 2008 Act. That government also confirmed the role of Infrastructure UK (its formation had been announced by the previous government in 2009). The position of the Treasury as the ministry aspiring to dominate this policy field was apparently confirmed too by the publication in October 2010 of the first "National Infrastructure Plan" (HM Treasury 2010). This made a first approach to considering all the factors involved in key infrastructure, covering finance and regulatory reform more than planning issues (Marshall 2010). However it was far from being a plan in the spatial planning sense, more just a bundling up of some projects and principles, and it is unlikely that the revised version promised for the end of 2011 will be any more spatialised.

The NPSs were originally to number 11, for energy sectors, transport, water, and waste; those for airports and water supply will probably not now go ahead, under the post 2010 government. Whilst in the past there have been long term policy statements by governments about each sector, sometimes with spatial content, normally taking the form of White Papers, the NPSs are intended to have greater weight. They are very definitely sectoral planning instruments, though some would have detailed spatial content (such as that for nuclear power stations, identifying 10 sites, two being 
dropped in 2010). There was much criticism when the first set (for energy and ports) was published in November 2009; the energy set was reissued in October 2010, with few changes by the new government. The ministry in which planning is situated had very little say over their content, and there is no national consensus in the cases so far published about what the preferred policy direction should be. It may be that such public policy making has been so little practised in recent decades, that there has been a loss of collective memory and capacity as to how to create such long term strategies. This was in spite of some efforts by the New Labour governments from about 2005 to create a better base, through the appointment of review bodies on housing, transport and climate change.

What is distinctive about the new system is that some engagement is being made with the national level for big questions, to some degree spatially. This is likely to be complemented by the work of the newly created Marine Management Organisation, in making a Marine Spatial Plan, as in many European states. The pressure is then created to move to an integrated approach for terrestrial planning, instead of isolated sectoral statements. The post-2010 UK government looks unlikely to grasp this nettle, despite having at one stage promised a national planning framework for England. It appears at the time of writing that this will be no more than a severe precis of existing Planning Policy Statements. Nevertheless, the move to NPSs raises very interesting questions about the role of the state in this highly neoliberalised context. Does an "efficient" capitalist state in contemporary circumstances (climate change challenges of low carbon, limited public finance, overmighty infrastructure corporations) "need" to re-engage with long term public steering? How would this work in a relatively small and densely occupied country like England, with an essentially unitary government, weak or non existent regional structures and debilitated local authorities?

This may be where the issue of the material and imaginary historical geography of England/UK becomes critical. The political economic situation is clear enough (although there may well be regulatory regime reforms, especially for energy), and the constitutional position of England is unlikely to be subject to big change. The major questions may lie in what is in the minds of politicians and people. England's geography is difficult territory for any major change, whether a new north-south high speed rail, expanded airports, onshore wind farms or new nuclear power stations. It is certain that all these will be fought tooth and nail, as they have been in the past. There is little clear image of a future England, in fact not even competing clear imaginaries. Probably the dominant imaginary in the south is a rural idyll, with easy car mobility and wealth from the cash cow of London. This clashes with perhaps more industry or resource based visions elsewhere in the country. How planners or policy makers more widely might get from this year zero to a more fully grasped idea of futures, without the decades of debate which three of my European cases have behind them, is hard to say. Possibly a study within the government Foresight programme, Land Use Futures, was the first sign of wider long term thinking, at its publication in March 2010 (Government Office for Science 2010). A research programme continuing from this report's explorations might begin to take these questions into government.

Looking across the European cases - what models of national level planning activity? 
Just these three states (four cases) reveal highly varied approaches to national level planning. Each matches in some sense recent and current "needs" of each country, but this is not to bless them as adequate or appropriate for future challenges. One thing I have noticed in each country is a very high level of dissatisfaction with what is being done in these areas in each country, amongst experts I have spoken to. The reasons for this dissatisfaction are probably different in each country, but this at least indicates common question marks about the way in which states are dealing with large infrastructural and spatial steering.

A brief characterisation of the models now operating gives the following:

- Scotland has a formalised statutory national schema, somewhat reminiscent of the Dutch system, though with less control of resources and finance, and a tighter linking to infrastructure projects. It remains to be seen how this plays out, in implementation.

- Germany has the next most formal set of arrangements, but in much lighter, strongly federalised form, based on collaborative working, mixed up with the political fighting between levels common to all models. It is a model which might well have lessons for other states, with perhaps the rather weak, incremental approach attractive to current neoliberal and decentralised times, but with a strong core in road and rail planning.

- France has a strongly composite model, but without the formalisation evolved in Germany. The mix of powers gives overall a fragmented central role, but one which via interscalar negotiation manages to make some sense, partly through a continuing idea of the national framing (increasingly absent in more centrifugal cases like Spain, the UK and Belgium). The centre still holds, but largely through sectoral planning and residual ideas carried through from earlier policy making eras.

- England, up to 2009, had a sporadic mix of sectoral strategising and leaving to market, neoliberal style, but within a strongly centralised governmental system. The 2008 Act set first steps to a new system, so the coming years may see a move to more formalised all England (comprehensive or just sectoral) arrangements, or relapse to minimal spatial strategic work.

Figure 2 shows some simplified "messages" from the cases.

There are therefore various dynamics at work here, with complexity and fuzzyness to the fore in two cases (England and France), and some more formality, at least apparently, flowing in the others. This is probably only a matter of degree, in that all cases have had a major dose of political manoeuvering built into processes, however formal or fuzzy - this is something remarked on as much in the Netherlands and Germany as in the most obviously raw politics of France and Spain. But the division may be an important matter of degree, with the approaches in the more formal cases giving more opportunity for democratic deliberation at national level, and between that level and others, as against the more invisible fighting out of the other cases.

\section{$\underline{\text { Conclusions }}$}


It should be clear therefore that national spatial planning or policy making is of real significance in these states. However it takes novel, often rather fuzzy and confusing shapes, with big variation between the three (four) cases. There is no common response. The most liberalised, the UK, has resuscitated national planning approaches, in England via sectoral planning mechanisms and attempts at speeded up consenting, in Scotland via comprehensive spatial planning. The least liberalised, France, still relies in part on old style sectoral planning, but equally on evolved multilevel negotiated governing, within a still coherent national idea. Germany uses "soft" national federal planning, alongside the post unification investment drive, within a now decomposing force field (especially in energy and transport), to rather mixed results - but as in France, the system functions. So the most liberalised case refinds sorts of planning, perhaps by some kind of necessity, whilst the others develop more complex governing forms.

The whole infrastructure field is caught in a powerful and tense pull of forces, making it a deeply problematic area for public action. Such tensions are very difficult to avoid, given current ideological positions of state leaders. Planners and policy makers generally therefore are obliged to act in subtle and adaptive ways. A combination of political economy, governmental forms and spatial mentalities has encouraged the evolution of a range of lighter national spatial planning arrangements in the three (four) cases studied, with only Scotland standing out to some degree as a more formal model. It must be questioned whether these are likely to be up to the challenges being posed for countries in the present period. It can be argued that these challenges, for example to move to low carbon societies or to restructure to more sustainable economic systems, would need much more powerful interventions at the levels of national states. Of course there are plenty who would argue that other approaches would be better, whether led at continental level by the EU, or based on much more developed market mechanisms, perhaps combined with serious fiscal measures relying largely on price signals. The balance of different types of approaches is extremely controversial. The models I have studied have all evolved because to a degree they fitted the political and economic changes of recent decades. They therefore have a large amount of momentum, having evolved with the grain of these changes. Ideologies and mentalities are carriers of these models, in part, and without a change in these realms of ideas, new models may be implausible.

In the field of infrastructure, investment has moved, if variably, into the hands of private often globalised corporations. In the UK these are often private equity companies, with limited interest in long term substantive goals. In all countries these sectors have been or are becoming attuned in large part to stock market demands, and so need considerable encouragement to collaborate in socially or politically set goals. The recent period has been something of a half way house, with bodies like EDF or Spanish energy giants retaining some of their public service culture and mode of planning. It is not clear how long this will continue, particularly under EU liberalisation pressure. This is the field within which national spatial planning now moves, and it is not an easy terrain for the typical societally oriented aspirations of most spatial planners.

It is probable that these national level planning models, varied though they are, are too weak to have much success in contributing to large societal transitions. No doubt 
they can manage business as usual, slight adjustment at the margins. But in the face of the major private centres of powers, and the loss of authority to subnational governments in most countries, it seems unlikely that the loose and partial national level mechanisms identified can have the force to generate shared new approaches to living in each country. The very different Dutch case, with formal national spatial planning, looks better equipped to meet such massive transitional challenges. But the light touch and sectoralised models analysed here are the present realities. Perhaps it is time for students of planning to subject this scale of planning to the same sort of attention frequently given to the local or city regional levels, in an attempt to put forward more effective models which might fit better the coming decades.

\section{$\underline{\text { References }}$}

Adams, N., Alden, J. and Harris, N. (2006), Regional Development and Spatial Planning in an Enlarged European Union, (Aldershot, Ashgate).

Albrechts, L. and Mandelbaum, S. eds (2005) The Network Society: a new Context for Planning? (London, Routledge).

Aring, J. and Sinz, M. (2006) Neue Leitbilder der Raumentwicklung in Deutchland, disP, 165, pp. 43-60.

Brenner, N. (2004) New State Spaces, (Oxford, Oxford University Press).

Brenner, N., Peck, J. and Theodore, N. (2010), Variegated neoliberalization: geographies, modalities, pathways, Global Networks, 10, 2, pp. 1-41.

Brenner, N., Peck, J. and Theodore, N. (forthcoming) After neoliberalization?, Globalizations, 7.

Coutard, O. (1999) The Governance of Large Technical Systems (London, Routledge).

Duhr, S., Colomb, C. and Nadin, V. (2010) European Spatial Planning and Territorial Cooperation, (London, Routledge).

Dupuy, G. (1991) L'Urbanisme des Reseaux (Paris, Armand Collin).

Goodwin, M. Jones, M. and Jones, R. (2005) Devolution, constitutional change and economic development: Explaining and understanding the new institutional geographies of the British State, Regional Studies, 39, 4, pp. 421-436.

Government Office for Science (2010) Foresight Land Use Futures Project (London, Government Office for Science).

Graham, S. and Marvin, S. (2001) Splintering Urbanism (London, Routledge).

Haughton, G., Allmendinger, P., Counsell, D. and Vigar, G. (2010) The New Spatial Planning (Abingdon, Routledge).

Healey, P. (2007) Urban Complexity and Spatial Strategies (London, Routledge).

Healey, P. (2010) Making Better Places (Basingstoke, Palgrave).

HM Treasury (2010), National Infrastructure Plan 2010, (London, HMT).

Hodson, M. and Marvin, S. (2010) World Cities and Climate Change (Maidenhead, Open University Press).

Jackson, G. and Deeg, R. (2006) How Many Varieties of Capitalism? (Cologne, MaxPlanck-Institut fur Gesellschaftsforschung Discussion Paper 06/2).

Jessop, B. (2002) The Future of the Capitalist State (Cambridge, Polity).

Jessop, B. (2007) State Power: a strategic relational approach (Cambridge, Polity). Lijphart, A. (1999) Patterns of Democracy, (New Haven, Yale University Press).

MacLeod, G. (2001) New regionalism reconsidered: globalization, regulation and the recasting of political economic space, Progress in Human Geography, 21/4: pp. 50327. 
Marshall, T. (2010), Dissecting the first stab at a National Infrastructure Plan, Town and Country Planning, December, (London, TCPA).

Massey, D. (2007) World City, (Cambridge, Polity).

Massey, D., Amin, A. and Thrift, N. (2003) Decentering the Nation, (London, Catalyst).

MKRO (Standing conference of ministers responsible for spatial planning), (2006), Concepts and Strategies for Spatial Development in Germany, (Berlin, MKRO, BMBVS/BBR).

Monstadt, J. (2009) Conceptualizing the political ecology of urban infrastructures: insights from technology and urban studies, Environment and Planning A, 42, pp. 1924-1942.

Newman, P. and Thornley, A., (1996) Urban Planning in Europe, (London, Routledge).

Newman, P. and Thornley, A. (2005) Planning World Cities: Globalization and Urban Politics, (Basingstoke, Palgrave).

Salet, W. and Gualini, E. eds (2007) Framing Strategic Urban Projects: Learning from Current Experiences in European Urban Regions (London, Routledge).

Schmidt, V. (2002) The Futures of European Capitalism (Oxford, Oxford University Press).

Streeck, W. (2009) Re-Forming Capitalism, (Oxford, Oxford University Press). 


\begin{tabular}{|c|c|c|c|}
\hline State & $\begin{array}{l}\text { Political economic } \\
\text { features }\end{array}$ & $\begin{array}{l}\text { Constitutional } \\
\text { features }\end{array}$ & $\begin{array}{l}\text { Historical- } \\
\text { geographical } \\
\text { features / national } \\
\text { imaginaries } \\
\end{array}$ \\
\hline France & $\begin{array}{l}\text { Strong state role } \\
\text { remaining in some } \\
\text { infrastructure } \\
\text { sectors, alongside } \\
\text { deepening } \\
\text { liberalisation. }\end{array}$ & $\begin{array}{l}\text { Previous } \\
\text { centralisation } \\
\text { replaced by strong } \\
\text { shift in favour of } \\
\text { localised and } \\
\text { regionalised } \\
\text { governing levels. } \\
\text { But remaining a } \\
\text { unitary state. }\end{array}$ & $\begin{array}{l}\text { Strongly double } \\
\text { sided imaginary, } \\
\text { with national idea } \\
\text { remaining } \\
\text { powerful, but a } \\
\text { dispersed model } \\
\text { equally forceful, } \\
\text { pulling away from } \\
\text { a Paris dominated } \\
\text { idea of France. }\end{array}$ \\
\hline Germany & $\begin{array}{l}\text { Privatisation and } \\
\text { liberalisation } \\
\text { advanced, though } \\
\text { at later dates than } \\
\text { UK, and some } \\
\text { sectors retain } \\
\text { significant public } \\
\text { ownership (water, } \\
\text { ports, roads). }\end{array}$ & $\begin{array}{l}\text { Mature federal } \\
\text { system, with } \\
\text { elaborate balancing } \\
\text { processes leaving } \\
\text { federal level with } \\
\text { only moderate } \\
\text { powers. }\end{array}$ & $\begin{array}{l}\text { Powerful national } \\
\text { coherence, } \\
\text { especially in post } \\
\text { reunification } \\
\text { period, alongside } \\
\text { polycentric idea of } \\
\text { the country, } \\
\text { matched by strong } \\
\text { federalism. }\end{array}$ \\
\hline UK & $\begin{array}{l}\text { Early and extensive } \\
\text { privatisation and } \\
\text { liberalisation of } \\
\text { most infrastructure } \\
\text { sectors, with roads } \\
\text { as the only } \\
\text { significant publicly } \\
\text { owned sector in } \\
\text { England. But } \\
\text { strong regulatory } \\
\text { machinery in all } \\
\text { other sectors. }\end{array}$ & $\begin{array}{l}\text { Since } 1998 \text { four } \\
\text { separate governing } \\
\text { realms, with } \\
\text { England still } \\
\text { managed centrally } \\
\text { by UK state, and } \\
\text { Scotland, Wales } \\
\text { and Northern } \\
\text { Ireland with } \\
\text { significant powers } \\
\text { in several } \\
\text { infrastructure and } \\
\text { planning spheres. }\end{array}$ & $\begin{array}{l}\text { Uncertain idea of } \\
\text { UK following } 1998 \\
\text { devolution } \\
\text { settlements, } \\
\text { making all UK } \\
\text { conceptualisation } \\
\text { very difficult, and } \\
\text { no clear imaginary } \\
\text { shared on England. }\end{array}$ \\
\hline
\end{tabular}

Figure 1 Three analytical axes to examine national planning models 


\begin{tabular}{|l|l|}
\hline State or case country & Messages from analysis of national level planning \\
\hline France & $\begin{array}{l}\text { Shows how shift to more polyarchic negotiated polity can } \\
\text { be compatible with some continuing national steering } \\
\text { where a to some extent shared national imaginary remains } \\
\text { able to steer all-France discourses. }\end{array}$ \\
\hline Germany & $\begin{array}{l}\text { Shows scope for "soft" national planning instruments to } \\
\text { have value under current circumstances - but also limits in } \\
\text { such a strongly federalised state, in a period of advanced } \\
\text { fragmentation generated by privatisation and state budget } \\
\text { cuts. }\end{array}$ \\
\hline UK-England & $\begin{array}{l}\text { Pre 2008 regime showed tendencies within a hyper } \\
\text { liberalised polity. Post 2008 system shows response to } \\
\text { business pressures from the privatised infrastructure } \\
\text { industries, but this may be problematised by weak national } \\
\text { imaginary giving little consensus on most infrastructure } \\
\text { sectors - unresolved constitutional and political issues } \\
\text { affect planning scope just as much as the political } \\
\text { economy. }\end{array}$ \\
\hline Scotland & $\begin{array}{l}\text { All three axes enabled innovation to take place in national } \\
\text { level planning - new constitutional opportunity, different } \\
\text { political economy (slightly less privatisation than in } \\
\text { England) and clear idea of national futures. }\end{array}$ \\
\hline
\end{tabular}

Figure 2 Simplified "messages" from the analysis of the country cases

i This work was carried out as part of a project funded by an ESRC fellowship on Infrastructure and Spatial Planning (grant number RES-063-27-0157). This allowed me to examine practice in relation to planning big infrastructure in other EU states, as well as studying changes in England. Further details and full referencing, in the shape of working papers on Dutch, English, French, German, Scottish and Spanish experience, can be found at the following webpages :

http://www.brookes.ac.uk/schools/be/about/planning/projects/tmarshall.html 